UDC 66.095.2/661.71

\title{
DEVELOPMENT OF A NON-STATIONARY MATHEMATICAL MODEL FOR THE PROCESS OF POLYMERIZATION OF PROPYLENE
}

\author{
A.M.Aliyev, A.R.Safarov, I.V.Balayev, I.I.Osmanova, A.M.Guseynova, F.G.Bayramov \\ M.Nagiyev Institute of Catalysis and Inorganic Chemistry, NAS of Azerbaijan \\ agil_s@mail.ru
}

Received 20.06.2020

Accepted 07.08.2020

\begin{abstract}
The mathematical model has been developed for the process polymerization propylene proceeding under unsteady conditions due to the toxic effect of methylacetylene on it, leading to decrease of the productivity and quality of polypropylene. Non-stationary function to maintain the productivity at the optimum level obtained during the process in stationary conditions has been proposed. Using this mathematical model allow ones control the process, stabilize it at any time of the polymerization operation. The control scheme of algorithm of this process has been created.
\end{abstract}

Keywords: polymerization of propylene, non-stationary function, non-stationary model, initiator.

doi:

\section{Introduction}

Polypropylene (PP) is the second most common polymer after polyethylene in the world. Demand for it is growing steadily. It increases by $4-6 \%$ annually. Polypropylene of all grades is physiologically harmless, therefore it is widely used in medicine, in housing construction, as well as for various household products and consumer goods. On an industrial scale, PP are prepared by propylene polymerization using Ziegler-Natta catalysts. A feature of organometallic catalysts of the Ziegler-Natta type is the ability to impart a certain stereoregular structure (isotactic) to PP molecules, which determines the enhanced physicochemical properties of the polymer. Isotactic polypropylene is technically the most important and promising, since it has high rigidity and hardness. The necessary conditions for polymerization are the presence of a pressure of at least $10 \mathrm{~atm}$ and a temperature of up to $80^{\circ} \mathrm{C}$. The reaction time is $4-6 \mathrm{~h}$ in reactors with a volume of $50-120 \mathrm{~m}^{3}$. The conversion is $98 \%$. Polymerization is carried out in a solvent medium, usually a liquid hydrocarbon (gasoline, $n$-heptane, white spirit). The volume ratio of propylene:solvent is $1.5: 1[1,2]$.

The technological process for the production of polypropylene consists of the operations of preparing catalyst complex, polymerizing liquefied propylene, washing the polymer suspension, squeezing out the polymer by centrifugation, drying, granulating, filling and packag-

ing. Due to the not always achievable purity of propylene entering the polymerizer, the stationarity of the process is violated, that negatively affects on productivity of the resulting product, reducing it. This can be avoided by introducing in stationary kinetic model selected of function control mathematical model of the process that affords chance of directing the process to necessary side and preserving required productivity of polypropylene.

The mechanism and mathematical description of the process

Scientists of the University of Massachusetts studied the kinetics of suspension polymerization in a semi-batch reactor on the rac$\mathrm{Et}(\mathrm{Ind}) 2 \mathrm{ZrCl}_{2} / \mathrm{MAO}$ metallocene catalyst complex [3]. The main goal of their work was to determine the effect of monomer concentration and temperature on the course of polymerization, to develop a kinetic model, and to estimate kinetic constants. The work was carried out at three temperatures $\left(50,65\right.$ and $\left.75^{\circ} \mathrm{C}\right)$ and four partial pressures of the monomer $(1.5,2.5,3.2$, $3.8 \mathrm{~atm})$. As a result, the profile of the polymerization reaction rate was determined, which is characterized by the period between the activation of the process until its maximum rate is reached and the subsequent gradual chain termination (deactivation).

The kinetic mechanism of the process is represented by the following scheme: 
Initiation

Chain growth

Chain transfer to monomer

Deactivation (Chain break)

Secondary inclusion

Chain growth after a break

Chain transfer after a break

However, it was found that the rates of secondary inclusion, chain growth after a break and chain transfer after secondary inclusion hardly affects the reaction rate. Therefore, the simplified equation of speed, including initiation, chain development, chain transfer to the monomer and deactivation has the following form:

$$
r(t)=\frac{k_{\mathrm{r}} \mathrm{C}^{*} k_{\mathrm{in}} \mathrm{M}^{2}}{k_{\mathrm{d}}-k_{\mathrm{in}} \mathrm{M}}\left(\mathrm{e}^{-\mathrm{k}_{\mathrm{in}} \mathrm{Mt}}-\mathrm{e}^{-\mathrm{k}_{\mathrm{d}} \mathrm{t}}\right),
$$

where $C^{*}-$ active catalyst center; $\mathrm{C}_{\mathrm{d}}^{*}-$ inactive catalyst center; $\mathrm{D}_{i}-$ chain break with $i$-th monomer; $k_{\text {in }}, k_{\mathrm{r}}$ - chain initiation and growth rate constants, $1 \mathrm{~mol}^{-1} \mathrm{~s}^{-1} ; k_{\mathrm{d}}-$ chain break rate constant, $1 / \mathrm{s} ; \mathrm{M}-$ monomer; $\mathrm{P}_{i}-$ chain with $i$-th monomer; $\mathrm{R}_{\mathrm{i}}-$ active chain with $i$-th monomer; $t$ - contact time, s.

Arrhenius dependent on temperature at calculating of kinetic rate constants was assumed:

$$
k_{\mathrm{i}}(T)=A_{i} \exp \left[-\frac{E_{i}}{R T}\right],
$$

where the activation energy $E_{i}$ of the polymerization process and the preexponential factor $\mathrm{A}_{\mathrm{i}}$ were adjustable parameters for each rate constant $k_{i}$.

The constants of the kinetic model are shown in Table 1.

The thermal effect of propylene polymerization makes up about $58.7 \mathrm{~kJ} / \mathrm{mol}$ or $1385 \mathrm{~kJ} / \mathrm{kg}$ (2.4 times less than at ethylene polymerization).
$\mathrm{C}^{*}+\mathrm{M} \stackrel{k_{\text {in }}}{\longrightarrow} \mathrm{R}_{\mathrm{i}}$

$\mathrm{R}_{\mathrm{i}}+\mathrm{M} \stackrel{k_{\mathrm{r}}}{\longrightarrow} \mathrm{R}_{\mathrm{i}+1}$

$\mathrm{R}_{\mathrm{i}}+\mathrm{M} \stackrel{k_{\mathrm{ir}}}{\longrightarrow} \mathrm{D}_{\mathrm{i}}+\mathrm{R}_{\mathrm{i}}$

$\mathrm{R}_{\mathrm{i}} \stackrel{\mathrm{k}_{\mathrm{d}}}{\longrightarrow} \mathrm{D}_{\mathrm{i}}+\mathrm{C}_{\mathrm{d}}^{*}$

$\mathrm{R}_{\mathrm{i}}+\mathrm{M} \stackrel{k_{\mathrm{s}}}{\longrightarrow} \mathrm{P}_{\mathrm{i}+1}$

$\mathrm{P}_{\mathrm{i}}+\mathrm{M} \stackrel{k_{\mathrm{sp}}}{\longrightarrow} \mathrm{R}_{\mathrm{i}+1}$

$\mathrm{P}_{\mathrm{i}}+\mathrm{M} \stackrel{k_{\text {str }}}{\longrightarrow} \mathrm{D}_{\mathrm{i}}+\mathrm{R}_{\mathrm{i}}$

This makes possible to remove the heat of polymerization through the jacket of the apparatus, cooled by water, without resorting to special methods of heat removal (boiling solvent, gas circulation etc.) [3]. In this regard, the heat balance of the process can be described by the equation:

$$
q M=C_{p}\left(T-T_{0}\right) \mathrm{G}_{w},
$$

where $q$ - the thermal effect of reaction, cal $/ \mathrm{kg}$; $\mathrm{M}$ - monomer amount, $\mathrm{kg} / \mathrm{h} ; C_{p}$ - heat capacity of water, cal $\mathrm{kg}^{-1} \mathrm{~K}^{-1} ; T$ - reactor temperature, $\mathrm{K} ; T_{0}$ - cooling water temperature, $\mathrm{K} ; \mathrm{G}_{\mathrm{w}}-$ water amount, $\mathrm{kg} / \mathrm{h}$.

With increasing temperature, the reaction rate and, consequently, the yield of polypropylene are increasing. From this point of view, it would be advisable to maintain the temperature as high as possible. In this case, the heat of reaction would be improved due to the temperature difference between the coolant and the reaction mass. However, with an increase of temperature above $80^{\circ} \mathrm{C}(353 \mathrm{~K})$, the yield of atactic polypropylene increases significantly and the yield of isoatactic decreases.

Therefore, at the temperature of the reactor $T$, determined from equation (4),

$$
T=\frac{q M+C_{\mathrm{p}} T_{w} G_{\mathrm{w}}}{C_{p} G_{w}},
$$

\begin{tabular}{|c|c|c|c|}
\hline Parameters & $k_{\text {in }}, l \mathrm{~mol}^{-1} \mathrm{~s}^{-1}$ & $k_{\mathrm{r}}, l \mathrm{~mol}^{-1} \mathrm{~s}^{-1}$ & $k_{\mathrm{d}}, 1 / \mathrm{s}$ \\
\hline $\ln A$ & 10.24 & 24.05 & 13.42 \\
\hline$E_{\mathrm{i}}(\mathrm{kDj} / \mathrm{mol})$ & 43.05 & 52.32 & 62.03 \\
\hline$T^{0} \mathrm{C}$ & - & - & - \\
\hline 50 & $3.07 \cdot 10^{-3}$ & 97.5 & $6.36 \cdot 10^{-5}$ \\
\hline 65 & $6.27 \cdot 10^{-3}$ & 231 & $1.77 \cdot 10^{-4}$ \\
\hline 75 & $9.74 \cdot 10^{-3}$ & 395 & $3.34 \cdot 10^{-4}$ \\
\hline
\end{tabular}

a restriction should be imposed: $T \leq 353 \mathrm{~K}$.

Table 1. Kinetic constants 
Both working pressures, and the temperature, also significantly affect the rate of polymerrization of propylene. The reaction rate is a linear function of the partial pressure of propylene, that is, how many times the pressure increases, so many times the polymerization will increase. However, increasing the pressure leads to a sharp increasing the solubility of propylene in the hydrocarbon solvent. High solubility leads to a great increase in the cost of propylene evaporation, solvent vapor condensation and propylene compression during the evaporation stage. In addition, the conduct of the polymerization process at high pressures requires increasing the pressure in the pipelines of liquids (propylene, solvent, catalyst complex) while entering to the reactor, which complicates operation [5]. Taking into account the number of these features the polymerization process of propylene at conduct in a solvent medium pressure in the reactor remains constant, equal to $10 \mathrm{~atm}(\mathrm{dP} / \mathrm{d} \tau=0)$.

Equations (2), (5) constitute the mathematical model of the process proceeding under stationary conditions, provided that pure propylene is introduced into the polymerization reactor. However, during the pyrolysis of propane, in addition to propylene, by-products are also formed, containing the small amount of methylacetylene, which is difficult to separate from the reaction mixture and pollutes the raw feed to the polymerization. Despite the fact that it undergoes the selectively hydrogenation at the EthylenePolyethylene plant in an isothermal tubular reactor and is partially converted into propylene, however, even the remaining insignificant part of methylacetylene (1-3 ppm), interacting with the initiator, leads to the formation of undesirable for the polymerization process products, as a result of what the amount of disintegrating initiator (active catalyst complex) per unit time increases, which leads to a decrease in the molecular weight of the polymer, i.e. its quality.

To suspend the decomposition of the initiator, by as proposed the function that takes into account the toxic effect of methylacetylene on it. Poisoning occurs on the account of adsorbing methylacetylene contained in the feed stream and which is a poison for the initiator. We assume that the speed of its movement from the flow to the centers of the initiator is proportional to the number of unpoisoned centers and the concentration of the poison in the gas phase. It, in turn, is equal to the speed of movement of the total number of active centers $\left(C_{\mathrm{t}}\right)$ from the surface:

$$
-\frac{\mathrm{d} C_{\mathrm{t}}}{\mathrm{d} t}=\frac{\mathrm{d} C_{\mathrm{pc}}}{\mathrm{d} t} \mathrm{k}\left(C_{\mathrm{c}}^{\mathrm{t}}-C_{\mathrm{pc}}\right) C_{\mathrm{p}},
$$

where $C_{\mathrm{c}}^{\mathrm{t}}$ - initially present the total number of centers (active); $C_{\mathrm{pc}}-$ concentration of poisoned (inactive) centers; $\left(C_{\mathrm{c}}^{\mathrm{t}}-C_{\mathrm{pc}}\right)-$ number of non-poisoned centers; $C_{\mathrm{p}}-$ concentration of poison (methylacetylene) in the gas phase; $C_{t}-$ total number of active centers.

Dividing (1) on $\mathrm{C}_{\mathrm{c}}^{\mathrm{t}}$ and denoting by $\mathrm{Y}$ part of the poisoned centers from their total number $Y=\frac{C_{\mathrm{pc}}}{C_{c}^{t}}$, we obtain from (1):

$$
\frac{\mathrm{d} Y}{\mathrm{~d} t}=k(1-Y) \cdot C_{\mathrm{p}}
$$

integrating which, we have:

$$
(1-\mathrm{Y})=\mathrm{e}^{-\mathrm{ktC}}
$$

Part of the centers suitable for adsorption $-(1-Y)$, is the activity of the initiator. Denoting $1-Y=\theta$ and considering that the concentration of poisons $C_{\mathrm{p}}$ is proportional to the amount of raw materials supplied for polymerization $\left(C_{\mathrm{p}} \sim F_{\mathrm{C} 3}\right.$ H6), we obtain the following expression for the initiator deactivation function:

$$
\theta=\mathrm{e}^{-\mathrm{k} \cdot \mathrm{t}(1-\alpha) \mathrm{F}_{\mathrm{C}_{3} \mathrm{H}_{6}}},
$$

where $k$ - the rate constant of the decomposition of the initiator depending on reaction time equal to $k=A e^{-\frac{E_{i n}}{R T}} ; T$ - process temperature, $\mathrm{K}$; $A$ - preexponential factor; $\alpha$ - mole fraction of methylacetylene in raw material; $F_{\mathrm{C}_{3} \mathrm{H}_{6}}-$ amount of propylene entering the polymerizer, $\mathrm{kmol} / \mathrm{h} ; t$ - reaction time, $\mathrm{h} ; E_{\mathrm{in}}$ - activation energy of the 
initiator decomposition reaction, $\mathrm{kJ} / \mathrm{mol} ; \mathrm{R}$ - gas constant, $\mathrm{kDj} /(\mathrm{mol} \cdot \mathrm{K})$.

By least square method [6] hase been found: $\mathrm{k}_{0}=0.55 \cdot 10^{-6}, E=21.35 \mathrm{kDj} / \mathrm{mol}$.

To maintain the rate of polymerization and obtain polypropylene of the same quantity and quality as under stationary conditions (without taking into account the undesirable effect of methylacetylene), we introduce in the equation of the process rate going under stationary conditions (2) the nonstationarity function $\theta$, which will correct the change in the activity of the catalyst depending on the reaction time:

$$
r(t)=\frac{k_{\mathrm{r}} \mathrm{C}^{*} k_{\text {in }} \mathrm{M}^{2}}{k_{\mathrm{d}}-k_{\mathrm{in}} \mathrm{M}}\left(\mathrm{e}^{-k_{\mathrm{in}} \mathrm{Mt}}-\mathrm{e}^{-k_{\mathrm{d}} \mathrm{t}}\right) \theta .
$$

Equations (5), (10), with regard for expression (9), will form a complete mathematical model of the propylene polymerization process under unsteady conditions, the use of which will allow maintain the productivity of polypropylene on the required optimum level.

Figure presents the flowchart of algorithm of the control of this process for the propylene polymerization process proceeding under nonstationary conditions, with a description of the actions performed in the blocks.

Blocks 1,2. Input of initial data for the calculation according to the non-stationary model, including $\mathrm{g}_{\mathrm{C}_{3} \mathrm{H}_{6}}$ and $\mathrm{g}_{\text {in }}$. Block 3. Calculation of the current value $\mathrm{g}_{\mathrm{pp}}$. Block 4. Comparison $\mathrm{g}_{\mathrm{pp}}$ with its optimal value $g_{\mathrm{pp}}^{\mathrm{opt}}$ found when optimizing the CTC under stationary conditions. If the stated condition $\mathrm{g}_{\mathrm{pp}}^{\text {nonst }} \sim \mathrm{g}_{\mathrm{pp}}^{\text {opt }}$ is fulfilled, the input values of propylene and initiator are fixed and transmitted to the mode stabilization unit 13. If this condition is violated, we will alternately change the values of the parameters $\mathrm{g}_{\mathrm{C}_{3} \mathrm{H}_{6}}$ and $\mathrm{g}_{\text {in }}$ in order to obtain the specified polypropylene productivity. Block 5 . With a positive value of $\left(\mathrm{g}_{\mathrm{pp}}^{\text {nonst }}-\mathrm{g}_{\mathrm{pp}}^{\mathrm{opt}}\right)$, we will de- crease the propylene feed, with a negative value - we will increase it (blocks 6,7). Block 8. The stated condition $\sim\left(g_{\mathrm{pp}}^{\text {nonst }} \sim \mathrm{g}_{\mathrm{pp}}^{\text {opt }}\right)$ is checked. If it is fulfilled, then the signal about the required amount of propylene is sent to the input block 2 of the initial data and the calculation starts at the new value of $\mathrm{g}_{\mathrm{C}_{3} \mathrm{H}_{6}}$ and the initial value $\mathrm{g}_{\text {in }}$. If not, then we proceed to correct this situation by varying the second parameter - the amount of the supplied initiator. Block 9. Find the difference between $\mathrm{g}_{\mathrm{pp}}^{\text {nont }}$ and $\mathrm{g}_{\mathrm{pp}}^{\mathrm{opt}}$. If it is positive, then we decrease the initiator feed (block 10), if it is negative, we increase it (block 11). Block 12. Check the condition $\sim\left(g_{\mathrm{pp}}^{\text {nonst }} \sim \mathrm{g}_{\mathrm{pp}}^{\text {opt }}\right)$. If it is executed, then the values of the input parameters $\mathrm{g}_{\mathrm{C}_{3} \mathrm{H}_{6}}$ and $\mathrm{g}_{\mathrm{in}}$ are fixed. By alternately changing the input values of propylene and initiator, the polypropylene yield will reach optimum. The selection $\Delta \mathrm{g}_{\mathrm{C}_{3} \mathrm{H}_{6}}$ and $\Delta \mathrm{g}_{\text {in }}$ is carried out in such way that the value of the function $\theta$ is within the limits close to unity. If the condition is not met, then the selection of new initial data is in progress and the calculation of the new version begins (block 14).

\section{Conclusion}

On the basis of the developed mathematical model of the propylene polymerization process under non-stationary conditions, it is possible to more accurately determine the polymer yield already taking into account the poisonous effect of methylacetylene on the catalyst. In the case of a change in the productivity of polypropylene $\mathrm{g}_{\mathrm{pp}}$ compared with its amount obtained under stationary conditions by changing the value of $\theta$ it will be possible to regulate the process, keeping the polypropylene yield at the desired, optimal level. The new $\theta$ value is obtained by alternately changing the amounts of propylene $g_{\mathrm{C}_{3} \mathrm{H}_{6}}$ and initiator $\mathrm{g}_{\text {in }}$ fed to the polymerizer. 


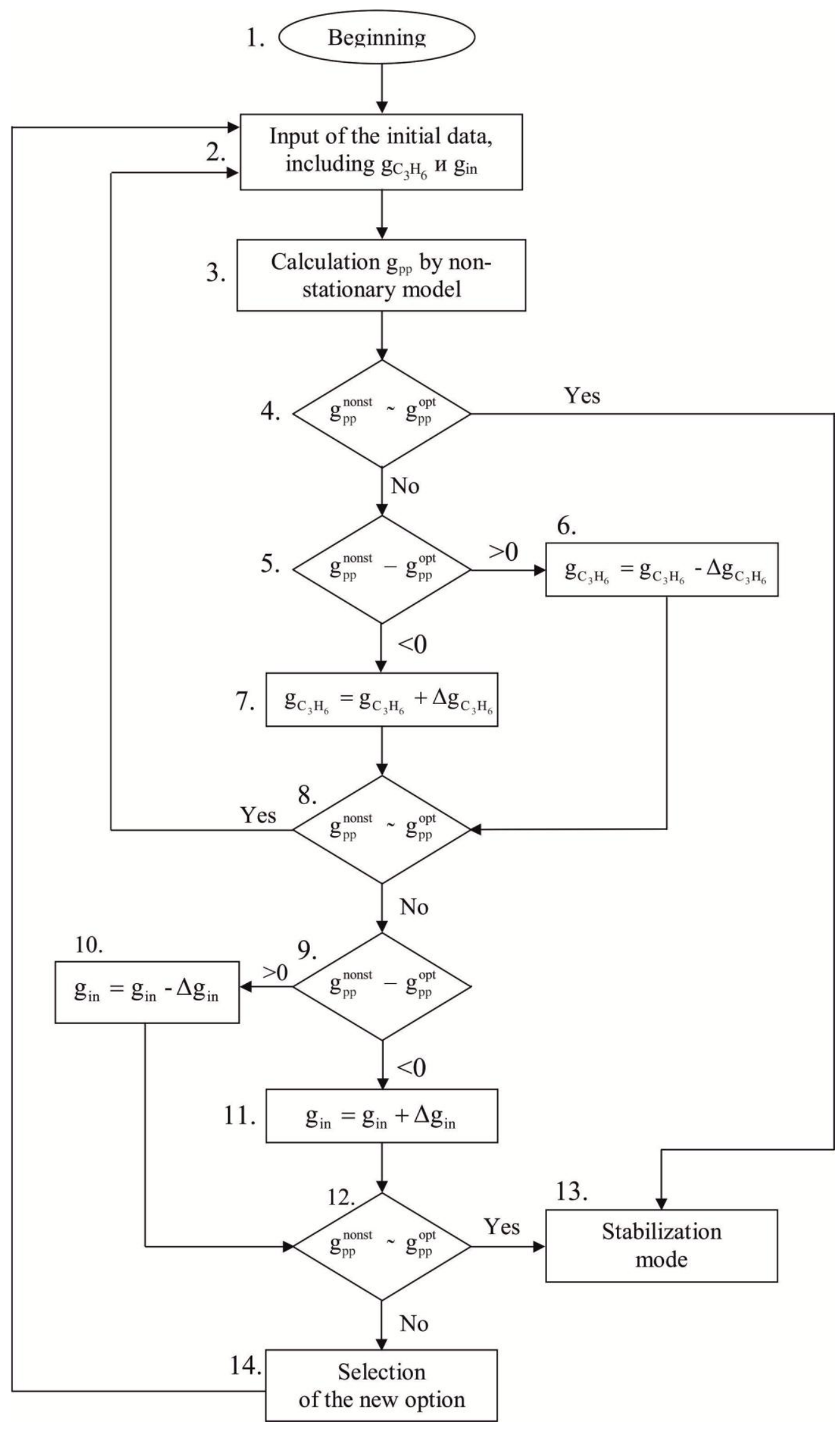

The flowchart of algorithm of the propylene polymerization process control. 


\section{References}

1. Ivaniukov D.V., Fridman M.L. Polipropilen. M.: Himiia, 1974. $268 \mathrm{~s}$.

2. White Dzh., Choi`d D. Polietilen, polipropilen i drugie poliolefiny. Izd-vo: Professiia, 2006. 262 s.

3. Ramon A.Gonzalez-Ruiz, Bernabe Quevedo-Sanchez, Roberrt L.Laurence, Michael A.Henson, E. Bryan Coughlin. Kinetic Modeling of Slurry Propylene Polymerization using rac-Et(Ind) $2 \mathrm{ZrCl}_{2} / \mathrm{MAO}$
American Institute of Chemical Engineers Journal (AIChE Journal). 2006. V. 52. No 5. P. 1824-1835.

4. Usacheva T.S. Obshchaia himicheskaia technologiia polimerov. Ch. 2. Osnovy tekhnologii sinteza polimerizatcionnykh polimerov: GOU VPO Ivan. gos. him.-tekhnol. un-t. Ivanovo. 2006. $60 \mathrm{~s}$.

5. Korshak V.V. Tekhnologiia plasticheskikh mass. M.: Himiia, 1985, $560 \mathrm{~s}$.

6. Balayev V.A., Məmmədov N.S. İdarəetmə obyektlərinin riyazi modellərinin alınması. Bakı, 2010, $411 \mathrm{~s}$.

\title{
PROPILENIN POLIMERLOŞMכ PROSESININ QEYRI-STASIONAR RIYAZI MODELININ YARADILMASI
}

\author{
A.M.Oliyev, A.R.Səfərov, İ.V.Balayev, İ.İ.Osmanova, A.M.Hüseynova, E.F.Oliyev
}

Qeyri-stasionar şəraitdə gedən propilenin polimerləşmə prosesinin riyazi modeli yaradılıb. Bu qeyri-stasionarlı̆̆ın əsas səbəblərindən biri propanın piroliz zamanı məqsədli məhsuldan - propilendən əlavə metilasetilenin yaranmasını qeyd etmək olar. Metilasetilenin polimerləşmə prosesində zəhər təsirli iştirakı, alınan polipropilenin məhsuldarlığını və keyfiyyətini aşağı salır. Məhsuldarlığı optimal səviyyədə saxlanılması məqsədilə metilasetilenin zəhərverici təsirini nəzərə alan qeyri-stasionar funksional asılılıq təklif olunub. Asılılı̆̆ prosesin riyazi modelinə daxil etməklə polimerləşmə qurğusunuda gedən prosesin istənilən zaman stabilləşdirməsinə imkan verəcək. Baxılan prosesin idarəetmə algoritminin blok sxemi tərtib edilib.

Açar sözlor: propilenin polimerlaşməsi, qeyri-stasionar funksiya, qeyri-stasionar model, inisiator.

\section{РАЗРАБОТКА НЕСТАЦИОНАРНОЙ МАТЕМАТИЧЕСКОЙ МОДЕЛИ ПРОЦЕССА ПОЛИМЕРИЗАЦИИ ПРОПИЛЕНА}

\section{А.М.Алиев, А.Р.Сафаров, И.В.Балаев, И.И.Османова, А.М.Гусейнова, Э.Ф.Алиев}

Разработана математическая модель процесса полимеризации пропилена, протекающего в нестационарных условиях из-за отравляющего воздействия на него метилацетилена, приводящего к снижению производительности и качества полипропилена. Для сохранения производительности на оптимальном уровне, полученном при проведении процесса в стационарных условиях, предложена функция нестационарности, использование которой в математической модели позволит управлять процессом, стабилизируя его в любой момент времени работы полимеризатора. Разработана блок-схема алгоритма управления процессом полимеризации пропилена.

Ключевые слова: полимеризация пропилена, функция нестациионарности, нестационарная модель, инициатор. 